\title{
PLANTING THE MORAL VALUES IN INTEGRATED ISLAMIC MIDDLE SCHOOL FITHRAH INSANI
}

\author{
Muhamad Imam Pamungkas ${ }^{1}$, Tiara Lidia Kani ${ }^{2}$ \\ ${ }^{1}$ Program Studi Pendidikan Agama Islam, Universitas Islam Bandung \\ ${ }^{2}$ Magister Pendidikan Islam, Universitas Islam Bandung \\ Email: ${ }^{1}$ m.imampamungkas@gmail.com, ${ }^{2}$ tiaralidiakani@gmail.com \\ DOI: https://doi.org/10.29313/tjpi.v9i1.6256 \\ Submitted: June 06th, 2020. Approved: June 26th, 2020. Published: June 26th, 2020
}

\begin{abstract}
Moral is the most important part of the pillars of Islam besides monotheism (tawhid) and the Shari'a. These three aspects are used as the basis of implementation for adherents, both in the application in the family environment, work environment, community environment, even wider environment, namely nation and state. For that reason, of course it is very important for us to know the details related to this character. The focus of this research is on the application and inculcation of moral values in Integrated Islamic Middle School Fithrah Insani, which until now has two branches of education units. This research uses a descriptive-analytic method with qualitative case study type. This research uses primary and secondary data sources. Data collection techniques carried out by interview, observation, literature, and documentation. As a conclusion, it was found that inculcation of moral values in Integrated Islamic Middle School Fithrah Insani was implemented in the activities of Recitation of the Qur'an (TTQ), Mentoring / Character Building, MABIT / CAMP, Assigning Students to Learn and Look for Teachers to Teach Themselves Outside School, and Public Lecture.
\end{abstract}

Keywords: Moral Value; Akblak; Integrated Islamic School; Fithrah Insani.

\begin{abstract}
Abstrak
Akblak adalab bagian terpenting dari rukun Islam selain taubid (taubid) dan syariat. Ketiga aspek inilah yang dijadikan landasan pelaksanaan bagi pemeluknya, baik dalam penerapan di lingkungan keluarga, lingkungan kerja, lingkungan masyarakat, babkan lingkungan yang lebih luas yaitu berbangsa dan bernegara. Untuk itu tentunya sangat penting bagi kita untuk mengetahui detail terkait karakter ini. Fokus penelitian ini adalah pada penerapan dan penanaman nilai moral di SMP Islam Terpadu Fithrah Insani yang hingga saat ini memilikei dua cabang satuan pendidikan. Penelitian ini menggunakan metode deskriptif analitik dengan jenis studi kasus kualitatif. Penelitian ini menggunakan sumber data primer dan sekunder. Teknik pengumpulan data dilakukan dengan wawancara, observasi, studi pustaka, dan dokumentasi. Sebagai kesimpulan, ditemukan bahwa penanaman nilai moral di SMP Islam Terpadu Fithrah Insani dilaksanakan dalam kegiatan Tilawah Alquran (TTQ), Pembinaan / Pembinaan Karakter, MABIT / CAMP, Menugaskan Siswa Belajar dan Melihat. bagi Guru untuk Mengajar Sendiri di Luar Sekolah, dan Kuliah Umum.
\end{abstract}

Kata Kunci: Nilai Moral; Akblak; Sekolah Islam Terpadu; Fithrah Insani. 


\section{INTRODUCTION}

The moral term is often heard and feels familiar to the hearing of all of us, especially for Muslims. For a Muslim, moral values must be inherent in him and implemented in everyday life, both vertically as we are familiar with the term Hablumminallab (relationship with God), or horizontally we are commonly known with the term Hablumminannas (relationship with human beings). Vertically, a Muslim should know well how to be moral to the Khalik (Allah), while horizontally, a Muslim must know well how to be moral to the fellow beings of Allah, as with our fellow humans, animals, plants, and the universe. Thus, a Muslim can synergize well to the Khalik and his creatures.

Apart from Tawhid and Shari'a, Morals or Akblak (Islamic term) is the most important part of the Islamic pillar. These three aspects are used as the cornerstone of implementation for the adherents, both in the application of the family environment, work environment, community environment, even the wider environment of nation and state. For that, it is certainly very important for us to know the details related to this morality.

Moral or akblak (Islamic term) is one of the main pillars of human life throughout history. History mentions that a state or nation becomes sturdy and strong when it is supported by strong morality, and vice versa, will collapse and be destroyed while the cause is corrupted (unblemished). This is also true for Muslims who are used to experience the heyday (golden), and noble character is one of the factors that supports the Islamic success (Pamungkas, 2016).

Moral values (noble) of course must go into all lines of life of every human being, including the world of education. Three aspects of education known as the Tri Education Center must become the main place in the cultivation of moral values, especially for children who are still in development.
The term Tri Education Centers were popularized by Ki Hajar Dewantara as the Father of National Education in Indonesia must have a good attachment (synergy). Tri Education Centers are the three main supporting facilities or media in education, especially for children. These facilities include family or parents (home), teachers (school), and the environment (community). There is also education that develops and runs in the family (home) including in informal education, while education that develops and takes place in schools including formal education (Pamungkas, 2017).

From these three aspects, the researcher will focus on the discussion in the school environment, which of course will also determine the mental and character development of students. Cultivation in schools must be included in learning, both intra-curricular and extra-curricular. Thus, the learning process and curriculum must be in line, from planning to evaluation.

The curriculum is something that is seen as a "plan" designed for success in the learning process under the responsibility and guidance of the education unit. Curriculum theorists argue that the curriculum aside from all aspects of planned activities, also includes events or activities carried out under the control or supervision of the education unit, then also informal ones such as co-curricular and extra-curricular activities. Although these activities are planned but not directly related to academic lessons in classes. The curriculum must be managed as well as possible so that the learning process can be carried out effectively and efficiently and can be done optimally productively (Rahminawati, et al., 2015).

Learning is the strength found in students to make a change based on the values, principles and theories of education. Supported by teachers (human resources), facilities, and procedures so that they can achieve the goals of education and learning, which is to make people who have faith and piety (Kani, et al., 2018). While moral teaching is a form of teaching that is oriented towards how someone (individual) behaves 
in his life, and on the formation of the soul. This teaching means a process of teaching and learning (PBM) in achieving goals so that what is taught has a laudable or noble character (Pamungkas, 2017).

Learning can also be said as a series of activities or activities that involve the environment and information that is planned in a way to facilitate students in learning. The intended environment is not only a place where the learning takes place, but also the media, methods, and equipment needed to convey information. Learning is an effort made by educators (teachers) to help students to receive the knowledge delivered and help facilitate the achievement of learning objectives (Amaliah, et al., 2018).

Based on the background about the urgency of morals in an educational institution, the researcher conducted a study in the period of year teachings 2019-2020 at an educational institution or school called Fithrah Insani, especially in the education unit at the level of Integrated Islamic Middle School. The focus of this research is on the application and inculcation of moral values in this school (Fithrah Insani), which until now has two branches of education units. The first school was established in the Ngamprah area of West Bandung Regency, and the second in the Baleendah area of Bandung Regency. In the 2020-2021 academic year, the Fithrah Insani Foundation is preparing two additional branches, namely Integrated Islamic Middle School Fithrah Insani 3 located in Margaasih, Bandung Regency and the fourth school is located in Padalarang, West Bandung Regency.

In implementing its programs in every educational unit established, Fithrah Insani Bandung Foundation has a vision and mission that has been very well designed. The vision is to make schools that educate students to have a basic and foundation of true aqeedah, Islamic character, knowledgeable, and independent. As for the mission described as follows: 1) educate and graduate students with excellence in Islamic personality, independence, skills, and science; 2) provide schools with quality Human
Resources, Facilities and Infrastructure; 3) managing schools that excel in science and technology using multi media and multi methods.

\section{RESEARCH METHODOLOGY}

This research was conducted using descriptive analytic methods and with the type of case study. While the type of data it uses is of a qualitative nature, which is a study or research that produces descriptive data in the form of written or oral data from people and observable behavior (Moleong, 2011). This research uses primary and secondary data sources. For primary data sources in this study research are leaders or policy makers at the Fithrah Insani Foundation Bandung and Integrated Islamic Middle School Fithrah Insani, such as the Foundation and the School Principal. Whereas for secondary data sources, researchers use documentation and other data relating to the cultivation of moral values in Integrated Islamic Middle School Fithrah Insani. For data collection techniques, conducted by interview, observation, literature, and documentation ,. Interview is the most dominant technique used by researchers in discussing this research. The last one is data analysis, which is in the form of descriptive analytic which is done in this research. For its implementation, this research was conducted in the period 2019-2020.

\section{RESULTS AND DISCUSSION}

\section{Theoretical Basis}

Starting the discussion in this study, the researcher will discuss in advance related to the theoretical basis that is the main reference and discussion, which is related to the inculcation of moral values. There are at least two theories that can be discussed, namely about the inculcation of values and morals. Based on the Indonesian Language Dictionary, planting is derived from the word 
planting which means process, act of planting, planting, or implanting.

Value is a set of feelings that are believed or beliefs as an identity that gives a special color or pattern to the pattern of feelings, thoughts, attachments, or behavior. Value means also the belief that makes someone act on the basis of desires / choices (Pamungkas, 2017). Hakim also mentioned that values are not only used as a reference to act and behave in society, but also serve as benchmarks for whether or not a symptom / phenomenon of action in the community. If there is a social phenomenon that is contrary to the value system that is recognized and adhered to by the community, it will get rejection from the community (Hakim, 2012). Whereas in the Indonesian Language Dictionary, value is interpreted as: 1) something that perfects humans according to their nature; 2) traits (things) that are important or useful to humanity.

Light, Keller, \& Calhoun limit the definition of value as: "Value is general notion that people share about what is good or bad, desirable or undesirable. Value transcends any one particular situation. ... Value people bold tends to color their whole way of life (D, et al., 1989).

Morals is an absorption word from

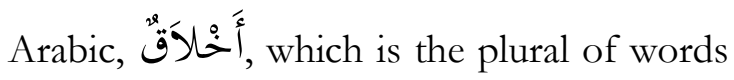

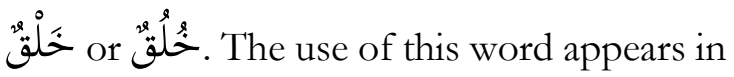
the Al-Qur'an when Allah states about the greatness of the Prophet Muhammad's character, namely in his words in surah alQalam verse 4: "And indeed, you are of a great moral character". Whereas in the Indonesian Dictionary, the word morals is commensurate with the word character. So, when explored further, the word moral is also commensurate with the word moral. In the Indonesian Dictionary, morals are teachings or doctrines about good and bad that are generally accepted about attitudes, actions, obligations, and so on. Thus, morals are related to good and bad values that are generally accepted in society. In general, morals is a complete system consisting of behavioral or reasoning characteristics that make a person extraordinary or special (Pamungkas, 2016).

In terminology, morals means the behavior of someone who is driven or based on a conscious desire to do good. Three scholars in the field of morals, namely Imam al-Ghazali, Ibn Miskawaih, and Ahmad Amin argued that morals are inherent traits in a person that can lead to good deeds without prior thought. Morals are also interpreted as a behavior, but the behavior must be done repeatedly and it is not enough to just do good deeds, or only at any time. So, a person can be said to have morality if they appear on their own, driven by motivation from within oneself and done without much thought considerations let alone considerations that are often repeated, so that it will be impressed as a compulsion to do. If the act is carried out in a forced condition, then it is not a reflection of morals (Rohman, 2012).

Thus, education and the learning process in any field must be harmonized with the sacred goal of forming a person and character with a noble character. So that progress and development in science and technology can lift human prestige and dignity, not the other way around, namely destroying it. In the end, with this noble character, Muslims can compete and bring even better benefits to the people.

\section{Profile of Integrated Islamic Middle School Fithrah Insani}

Before discussing about the school which is used as a research location, the author will discuss briefly about the foundation profile, which has now changed its name to the Fithrah Insani Foundation Bandung (YFIB), was founded on the establishment of the Integrated Islamic Elementary School (SDIT).

The establishment of the Fithrah Insani Integrated Islamic Elementary School (SDIT-FI) was initiated by several people, namely Maman Sulaeman, Didik Agus Triwiyono, Rachmat Tarman, Saepudin and Aries Fariady who are in Tanimulya Village, Ngamprah District, West Bandung District. In early 2002, they felt a sense of anxiety 
towards their children who were about to enter elementary school age. Their frustration began with the difficulty of finding an affordable school in terms of cost and space and good quality, both from the aspect of developing scientific insight or moral, mental and religious guidance. At that time, there were a number of Integrated Islamic Schools that were of good quality but relatively less affordable in terms of economic considerations and distance considerations.

From the background of these conditions, the initiators agreed to develop an Integrated Islamic Elementary School (SDIT), which was later given the name Fithrah Insani (FI). By learning from various schools that have used the concept of Integrated Islamic Schools earlier to emerge in Bandung and its surroundings, the initiators then began their steps by going through the following stages: 1) Socializing the idea of establishing an Integrated Islamic Primary School (SDIT), especially in the environment nearest in the Ngamprah District area; 2) Together with several other people in addition to making plans for the establishment of schools; 3) Forming the Fithrah Insani Foundation Bandung (YFIB) which will oversee the SDIT Fithrah Insani institution. The founding council was Didik Agus Triwiyono, Aam Salam Taufik, Saepudin, Maman Sulaeman, M. Mahdi Idris and Yatno. The establishment process was recorded through a notary deed no. 01 dated 20 March 2002 before a notary Iriawan, SH; 4) Establish an autonomous school management body namely the Institution of Fithrah Insani (BP-FI) through Decree of the Chairperson of the Fithrah Insani Foundation Bandung No. KEP-001 / YFI / 04/2002 dated April 11, 2002; 5) Make a memorandum of understanding on cooperation (MoU) with the Al-Mujahidin Mosque Family Council in the Tanimulya Indah Housing, Tanimulya Village, Ngamprah District, which contains an agreement on the use of local classes in the Al-Mujahidin Mosque for the implementation of learning; 6) Collaborate with the Integrated Educational Development Institution (LP2T) for Humanity to help develop school software; 7) Carry out technical preparations for the administration of schools, which include inventorying prospective students and opening registration of prospective students, selecting teacher candidates (in collaboration with the Integrated Educational Development Institute), holding open houses, educational seminars, etc. -other; 8) Implementation of teaching and learning activities for the first time in July 2002 with 24 students and two teachers (educators), namely Dra. Chairini (concurrently the Principal) and Dra. Hartati (concurrently homeroom teacher), and in January 2003 coupled with Dra. Dwi Handayanti as a teacher.

\section{Integrated Islamic Middle School (SMPIT) Fithrah Insani 1, Ngamprah}

In order to facilitate further education for elementary school graduates, including SDIT FI, then in 2006, the Fithrah Insani Bandung Foundation (YFIB) planned to establish an Integrated Islamic Middle School (SMPIT) Fithrah Insani. This idea was implemented with the construction of a junior high school located on Rawa Pojok Street No. 96 Tanimulya, Ngamprah. The building was built on land with an area of $1000 \mathrm{~m} 2$ and precisely began to be erected from September 2006 to June 2007. There is also its use, starting in the 2007-2008 school year with an initial number of students as many as 25 students from various schools. At this time Integrated Islamic Middle School Fithrah Insani (SMPIT-FI) is headed by Mr. Dadang Kusnadi as its leader.

The vision and mission of SMPIT-FI are the same, both in Ngamprah and in Baleendah. The vision is "Being a School Educating Students to be Independent, Islamic, Knowledgeable, and Excellent in Science and Technology ". While the mission is as follows: 1) Providing superior schools with quality Human Resources, facilities and infrastructure; 2) Manage schools with strong and professional management; 3) Educate 
and graduate students with Islamic personality, independence, skills and knowledge; 4) Schools that excel in science technology using English through multimedia and multi methods.
At present the number of students in SMPIT-FI 1 is 590 spread across 24 study groups (classroom). The complete data can be seen in the following table:

Table 1

Student Data in SMPT-FI 1

\begin{tabular}{|c|c|c|c|c|}
\hline Number & Class/Grade & Study Group & Total students & Implementation \\
\hline 1 & VII & 9 & 232 & Morning \\
\hline 2 & VIII & 7 & 175 & Morning \\
\hline 3 & IX & 8 & 183 & Morning \\
\hline amount & 3 & 24 & 590 & \\
\hline
\end{tabular}

Integrated Islamic Middle School (SMPIT) Fithrah Insani 2, Baleendah

In response to requests from the community in the Baleendah and surrounding areas, in 2012, the second school (SMPIT Fithrah Insani 2) was established having a school address at Laswi Street No.177B, Manggahang, Baleendah District, Bandung Regency and was led by Sofyan Arisandi, S.Pd as the first Principal and also as an English teacher. The second school (SMPIT-FI 2) has the same vision and mission as that which is written in the first school (SMPIT-FI 1). Currently SMPIT-IT 2 is led by Sopyan Saori, S.Pd as the Principal. While the number of students in SMPIT-FI 2 is 320 spread across 14 study groups (classrooms). The complete data can be seen in the following table:

Table 2

Student Data in SMPT-FI 2

\begin{tabular}{|c|c|c|c|c|}
\hline Number & Class/Grade & Study Group & Total students & Implementation \\
\hline 1 & VII & 5 & 120 & Morning \\
\hline 2 & VIII & 5 & 120 & Morning \\
\hline 3 & IX & 4 & 80 & Morning \\
\hline amount & 3 & 14 & 320 & \\
\hline
\end{tabular}

Analysis of Cultivating Moral Values in Integrated Islamic Middle School Fitrah Insani (SMPIT-FI 1 and SMPIT-FI 2)

Based on the limitation of the problem in this study, the researcher focused on the application and inculcation of moral values in SMPIT-FI 1 and SMPIT-FI 2. From the findings that have been obtained and analyzed, several programs were found that made the background of the formation of moral values in these schools. These programs include: 


\section{Recitations of the Qur'an and its Memorizes (TTQ)}

Recitations of the Qur'an and its Memorizes (Tilawah Tabfidz Qur'an) is two different worship activities. The first is reading the Qur'an (recitations of the Qur'an) and the second is memorizing the Qur'an (tabfidz, Qur'an). The definition of recitations in terminology is to read the contents of the Qur'an' and understand it. The meaning of reading is a process of physical and mental activity. This process can be done through reading knowledge and information that is beneficial to life. This is the main motivation that can encourage the development of an interest in reading. If the interest in reading has grown, and has begun to like to read, then reading habits will be embedded. The best place to develop that interest and develop reading habits is at home with a family atmosphere. There is also a time that you should start as early as possible, which is as a child (Rusni \& Lubis, 2017).

Term Tabfidz. Al-Qur'an is a word formation consisting of two syllables, namely Tabfidz and Al-Qur'an both of which have different meanings. The word Tabfidz is also a form of mashdar ghoir mim (Arabic) from the word hafiz̧ba - yabfazhu - hifz̧ban (Arabic), which means to encourage to memorize. Memorization comes from the basic word memorized which means the opposite of forgetting, which is always to remember and to forget a little. Memorization is also interpreted by maintaining, maintaining, and equating, then the person who memorized is called a guardian, caretaker, bodyguard and also which means memorization by heart (Amaliah, et al., 2018).

Generally, the program implemented in these schools is the same as in the terminology above and also with some programs in other schools. However, the difference is in the method that in these schools the method used was the Insaniyah

\footnotetext{
${ }^{1}$ Summer class is warming up in the classroom to equalize the temperature in learning (equalization of tahsin in reading the Qur'an), planting characters, forming an attitude of self-reliance, socializing the rules and speaking English, all done for 4 months.
}

method created by a team from the Fithrah Insani Foundation in Bandung. Insaniyah method is a method that targets children to be able to read in tartil (good and right reading) in a short time from children who have not been able to read the Qur'an at all because the Insaniyab method only has three volumes of basic books namely volumes 1, 2 and 3. Each of them contains only 16 pages which were implemented before the children entered the reading of the Qur'an's Manuscripts. The program begins with a Pre-test which is carried out during the summer class ${ }^{1}$ by grouping using the same test tool that is volumes insaniyah. The number of students in each group is 10-15 people. The person responsible for TTQ Insaniyah's activities is the TTQ Coordinator (Ibu Sri Rahayu, SH) and 10 TTQ teachers, while the current target is for all 589 students.

The implementation of this program usually uses class facilities and or mosques, and the time implementation is from Monday to Friday with a duration of about 2 hours. The reason for carrying out these activities is to preach and produce the best quality graduates who refer to quality assurance. Among the quality assurance states that "Memorize Al-Qur'an at least 1 (one) juz. (in addition to those who have memorized the basis)", and "Love recitations of Al-Qur'an with tartil readings". This program is carried out regularly (continue), which mostly takes about 10 hours / week.

\section{Mentoring / Character Building}

Character education is said to be a conscious and planned effort undertaken by schools, families, and communities to help young people understand, grow, and implement the core of moral values (Firdaus, et al., 2019). The importance of character planting - where the term character is identical with morals - in SMPIT FI, then the mentoring program was rolled out as a

During the summer class activities there were no cognitive academic exams, but the assessments were affective and psychotor, except in English where there were written examinations. 
medium in conveying character values (morals).

So the mentoring program conducted at this school is a character building program so that students have the basics of Islamic values that will form good character or noble moral. The person in charge of the activity is the Student Affairs and Mentoring Coordinators (Anjar and Mrs. Dwi) who are none other than TTQ teachers. The target of this activity is all students (589 students) in the school.

The usual place for this activity is in the classroom, mosque, field, lobby, even all the places in the school are used except the canteen. The implementation is every Friday (first week, second and third) at the first hour, which is at 07.40-08.50. The reason for carrying out these activities is to preach and produce the best quality graduates who refer to quality assurance, which is to have good character, be devoted to parents and respect for teachers, and worship awareness.

\section{MABIT / CAMP}

MABIT is Evening of Faith and Takwa Formation, which along with the MABIT program at this school changed its name to Camp. This program is more inclined towards coaching students whose targets are moral values, motivation, contemplation, and reflection. The program included public lectures, recitations and group motivations (1 group consisting of 10-15 students), morning and evening dhikr, prayer in congregation, qiyamulail (evening prayers) and morning exercise. The responsible for the activity are Islamic religious teachers and TTQ teachers who were given the mandate and all students (589 students) as the target of the activity. The place of implementation is different between male students (Ikhwan) and female students (akhwat), also for the place of rest or sleep.

There was also the implementation for seventh grade when The Introduction to School Environment (MPLS) and towards the Final Semester Assessment (PAS). As for classes 8 (eighth grade) and 9 (ninth grade), the implementation is only once in one semester, which is carried out when approaching the Final Examination / Assessment Semester (PAS). This activity was carried out against the background of the establishment of Fithrah Insani to preach and produce the best graduate quality that refers to quality assurance. The activity was carried out twice for seventh grade and once for eighth grade and ninth grade with duration for 2 days 1 night.

\section{Assigning Students to Learn and Look for Teachers to Teach Themselves Outside School}

This activity is an additional activity carried out outside of school hours to maximize the fostering of the Islamic character of students which has a good impact on the implementation of mentoring in schools. The person in charge of this activity is the SMPIT FI teacher who is adjusted to the zoning of the residence and if there is none, it is taken from outsiders who are assigned to go to school. The target activity is children whose morals are above average as a form of reinforcement for them in applying Islamic values in society.

The implementation is carried out on a safari basis (alternating from house to house according to the agreement of the study group) and is held once a week and adjusted to the agreement of the study group. The activity is carried out as a form of strengthening the character of students and to maximize coaching for students whose morals are above average.

\section{Public Lecture}

Public lecture is a program that deals with character development so that students have a good self-concept and Islamic insight. The person in charge of this activity is the Public Lecture Coordinator from the TTQ teacher who is under the Vice Principal for Student Affairs and Deputy Principal for Curriculum. This activity involves all students (589 students) as the target of the activity, which has the aim to understand the concept of Islam that is included in all aspects of life both in the world and the hereafter. In 
other words, to become a totality Muslim or Muslim Kaffah. Its implementation is every 4th week and its place is combined in the field. The activity was carried out departing from the purpose of the establishment of the school, which is to preach and produce the best quality graduates who refer to quality assurance, which is to have good character, serve parents and respect teachers, and worship awareness.

\section{CONCLUSION}

Based on the field data obtained and the results of the analysis, it is concluded that the inculcation of moral values in Integrated Islamic Middle School Fithrah Insani (SMPIT-FI) Bandung has been planned and implemented in various activities. These activities become a routine that is in accordance with the concept of morals, namely as a habitual activity. The activities to instill moral values include Recitations of the Qur'an and its Memorizes or Tilawah Tabfidz. Qur'an (TTQ), Mentoring / Character Building, Evening of Faith and Takwa Formation (MABIT) / CAMP, Assigning Students to Learn and Look for Teachers to Teach Themselves Outside the School, and Public Lectures.

\section{REFERENCES}

Amaliah, IN, Nuroni, E. \& Pamungkas, MI, 2018. Learning Tahfidz Al-Qur'an Using the Talaqqi Method (Case Study in Madrasah Ibtidaiyah Asih Putera Cimahi City). SPeSIA: Proceedings of Islamic Religious Education 4, No. 2, pp. 229-236.

D, L., S, K. \& C, C., 1989. Sociology. New York: Alfred A. Knopf.

Firdaus, M., Surbiantoro, E. \& Pamungkas, MI, 2019. Anti-Corruption Character Education in QS Ali Imran Paragraph 161. SPeSIA: Proceedings of Islamic Religious Education, 5 (2), pp. 190-197.
Hakim, L., 2012. Internalization of Islamic Values in the Formation of Attitudes and Behavior of Al Muttaqin Integrated Islamic Elementary School Students in Tasikmalaya City. Journal of Islamic Education, 10 (1), pp. 67-77.

Kani, TL, Nuroni, E. \& Pamungkas, MI, 2018. The Effect of Student Activity in Participating in the Muhadharah Program Against Motivation in Studying Islam in SMA 1 Margaasih, Bandung Regency. SPeSIA: Proceedings of Islamic Education, IV (1), p. 17

Moleong, LJ, 2011. Qualitative Research Methodology. Bandung: Teen Rosdakarya.

Pamungkas, I., 2017. Works: Synergizing Tri Education Centers. [Online] Available at: www.unisba.ac.id

Pamungkas, MI, 2016. Modern Muslim Morals. III ed. Bandung: Marja.

Pamungkas, MI, 2017. Implanting Islamic Values in Students' Prior Learning Activities in SMP PGII 1 Bandung. Ta'dib: Journal of Islamic Education, 6 (1), pp. 202-211.

Rahminawati, N., Halimi, A. \& Pamungkas, I., 2015. Analysis and Evaluation of Islamic Religious Education (PAI) Curriculum in Bandung Islamic University Based on the Indonesian National Qualification Framework (KKNI). Proceedings of the Social, Economic, and Humanities SNaPP, 5 (1), pp. 755-764.

Rohman, A., 2012. Habituation as the Basis for Cultivating Adolescent Moral Values. Nadwa: Journal of Islamic Education, 6 (1), pp. 155-177.

Rusni, A. \& Lubis, EE, 2017. Using Whatsapp Online Media in One Day One Juz Community Activities (ODOJ) in Increasing ODOJER Tilawah Interests in Pekanbaru City. JOM FISIP, 2 (1), pp. 1-15. 